\title{
Produções literárias da comunidade do CAp
}

\author{
Juçara Benvenuti*
}

\begin{abstract}
Resumo: O Concurso Literário do Colégio de Aplicação é uma Ação de Extensão realizada anualmente com o objetivo de estimular a produção escrita e de registrar as memórias da comunidade escolar. No ano de 2009 foi realizado de abril a junho, envolvendo a participação de professores do CAp e do Instituo de Letras da UFRGS, um técnico-administrativo e um representante da direção da escola. Os textos premiados aqui divulgados são identificados pelas autoras através de seus nomes e pseudônimos usados na inscrição.
\end{abstract}

Palavras-chave: Concurso Literário, Colégio de Aplicação, Vencedoras.

A Ação de Extensão "Concurso Literário do Colégio de Aplicação", que tem sido oferecida anualmente à comunidade capiana, em sua $6^{\text {a }}$ edição, no ano de 2009 , teve o seguinte calendário de atividades: seu lançamento realizou-se em 14 de abril, dia do aniversário do CAp e oportunizou um período de dois meses para as inscrições dos trabalhos. $\mathrm{O}$ julgamento dos textos inscritos ocorreu na semana de 15 a 19 de junho e a premiação aconteceu no dia 20, durante a Festa Junina, como tem ocorrido tradicionalmente desde a primeira edição do Concurso.

Os trabalhos inscritos no Concurso Literário do CAp são avaliados por três comissões julgadoras, uma para cada modalidade (Crônica narrativa, Charge e Poesia). A constituição das comissões

Professora de Língua Portuguesa do CAp/UFRGS. Mestre em Literatura. E-mail: 00010456@ufrgs.br 
varia a cada ano, mas sempre são incluídos três membros em cada uma, sendo professores do Departamento de Comunicação e do Departamento de Expressão e Movimento do CAp, de Língua Portuguesa e Literatura do Instituto de Letras da UFRGS, um representante dos Técnico-Administrativos e um representante da direção do CAp.

Os critérios analisados pelas comissões julgadoras na avaliação dos textos inscritos, previstos no regulamento do Concurso, são adequação ao tema (relacionado ao CAp), identificação com a modalidade escolhida (crônica, charge ou poesia), criatividade e originalidade, respeitadas as características intrínsecas de cada categoria (mirim, infanto-juvenil, juvenil e adulta).

$O$ reoferecimento da Ação vem mostrando aumento gradual do interesse da comunidade, bem como sua participação, seja na inscrição de trabalhos, seja no envolvimento das atividades decorrentes como divulgação e premiação.

As vencedoras do Concurso Literário na $6^{\mathrm{a}}$ edição foram:

- Modalidade: Crônica Narrativa

- Categoria: Infanto-juvenil

Pseudônimo: Tellus

Autora: Alexsandra Moresco de Moura - Aluna da Turma: 72

- Título do Trabalho: O Planeta Tellus

Há muito tempo, numa galáxia muito, muito distante, existia um pequeno planeta chamado TELLUS, com solos férteis, cobertos por florestas e existia água em abundância. No entanto, os seres ali existentes não tinham a preocupação com o meio ambiente e exploravam tudo o que natureza lhes fornecia sem dar nada em troca.

Alguns cientistas de TELLUS alertavam para as grandes mudanças climáticas que poderiam ocorrer no planeta, até mesmo sua extinção. Entretanto, para a classe dominante eles não eram levados a sério, eram considerados loucos e acusados de serem contra o progresso tecnológico. Os TELLIANUS tinham um enorme conhecimento na área de exploração espacial e desenvol- 
veram naves, que eram capazes de ir muito além da velocidade da luz e, dessa forma, imaginavam que podiam descobrir novas Galáxias e novos planetas semelhantes ao deles.

Porém, devido à exploração dos recursos naturais sem controle, o planeta TELLUS começou apresentar um grande descontrole no seu ecossistema, e as consequências foram catastróficas. Faltou chuva e consequentemente as florestas desapareceram, as fontes de água naturais cada vez tornavam-se mais escassas e começou a aquecer o planeta tornando-se um solo estéril, sem condiçóes para ter vida no local.

O Conselho TELLIANUS se reuniu e decidiu encaminhar centenas de naves para diversas Galáxias para que eles encontrassem um novo planeta para morar.

Uma das naves depois de viajar por muito tempo encontrou o Planeta Terra, e os poucos ETs que ainda restavam ficaram maravilhados com o que viram na Terra: muita água, florestas, montanhas e grandes cidades. E podiam lembrar alguma coisa do que representava o planeta deles. Eles começaram a estudar o comportamento do povo e seus costumes, pois queriam viver no planeta sem chamar atenção. Para isso se transformaram como se fossem seres humanos, dessa forma eles poderiam viver junto com os homens.

Com o passar das semanas e já integrado com a população, a preocupação da família de ET era escolher um colégio para a filha Lissa estudar. Chamou-lhes a atenção o Colégio de Aplicação, pois ele ficava junto de uma floresta. Foram até o local para saber como fazer para estudar no colégio, ficaram sabendo que deveriam participar de um sorteio. Inscreveram Lissa que, para felicidade de todos, conseguiu ser sorteada.

Entretanto, a grande preocupação da família era ver que aqui na Terra os humanos estavam repetindo os mesmos erros que ocorreram no planeta TELLUS. Eles através da Lissa montaram uma estratégia para que todos tivessem consciência da importância da preservação do meio ambiente. 
Lissa chamava a atenção de todos no Colégio, pois ela era muito inteligente e fazia campanha interna para despertar atenção dos colegas para a importância da conservação da floresta das proximidades do Colégio. E junto com os professores organizaram seminários para discussão do meio ambiente e para discutir quais seriam as melhores práticas para despertar a consciência ecológica nas pessoas.

Foi assim que o Colégio de Aplicação desenvolveu uma campanha que envolveu os alunos, a população, a imprensa, as Fundações do meio ambiente e muitas empresas de conservação ambiental.

Lissa estava muito feliz, pois o envolvimento dos colegas era muito grande, e eles começaram a plantar árvores no pátio do Colégio, a dar nomes a cada uma das plantas. Desta forma todos tomaram consciência de que era necessário fazer alguma coisa para melhorar o planeta Terra.

- Modalidade: Poesia

Categoria: Infanto-juvenil

Pseudônimo: Val

Autora: Valéria Sofia Bagatini - Aluna da Turma: Amora I

- Título do Trabalho: Minha bistória no CAp

Em 2005, na Alfa I, foi pura diversão, meu coração não parou de pular eu aprendi a escrever e a ler!

Em 2006, na Alfa II, foi pura diversão, meu coração não parou de pular eu aprendi a desenhar e a sonhar! Em 2007, na Alfa III, foi pura diversão, meu coração não parou de pular eu aprendi a multiplicar e a sonhar! Em 2008, na Alfa IV, foi pura diversão, meu coração não parou de pular eu aprendi a dividir e a fazer poesia! Em 2009, no Amora I, foi pura diversão, 
meu coração não parou de pular eu aprendi a medir e a imaginar! Imaginar o que serei no futuro, imaginar o que posso fazer para melhorar o meio ambiente imaginar se o que vou fazer ou estou fazendo está certo, imaginar se daqui a trezentos mil anos a humanidade ainda existirá, simplesmente imaginar e...

ter certeza de que o que estou fazendo agora pode me ajudar no futuro, certeza de que dividindo eu multiplicarei, certeza de que todo ato gera consequências, certeza de que se meus atos forem para somar estarei apta para enfrentar a matemática da vida!

- Categoria: Adulto

Pseudônimo: Butterffly 2009

Autora: Leonise Verzoni - Bibliotecária do Colégio de Aplicação

\section{- Título do Trabalho: Mãos de Mulher}

Mãos de mulher: um produto sensacional

Mãos perfeitas criadas por Deus

Com garantia de qualidade, especial

São as mãos que limpam, organizam

Preparam o alimento e enfeitam

As mesmas mãos que acariciam e afagam

As pessoas amadas, companheiros de jornada

Mãos que ajudam os amigos e fazem curativos

Mãos que salvam vidas, alimentam, curam e acariciam

Seres largados, seres queridos, seres esquecidos...

Mãos que aplicam receosas a injeção que dá a proteção

São as mesmas que transformam a matéria bruta em um coração

Modelam, bordam, costuram e tricotam com emoção

Consertam a torneira, cortam a grama, cuidam do jardim 
Pintam as paredes... os olhos... os lábios... as unhas e o sete Essas são as mãos que enviam mensagens de carinho Força, fé e esperança a uma lista de amigos

Manuseiam, colam e consertam os livros

E ainda apertam os parafusos das estantes no caminho $\mathrm{Na}$ tela, na teia, nas teclas de um computador Essas mãos armazenam a informação

Que vai enriquecer o conhecimento e o saber Dos alunos do Colégio de Aplicação. 